\title{
Media Promosi untuk Membantu Promosi Desa Wisata
}

\author{
Agus Aan Jiwa Permana ${ }^{1 *}$, Made Padmi Wirayani \\ 1,2 Prodi Manajemen Informatika, Universitas Pendidikan Ganesha, Singaraja, Indonesia
}

\section{ART ICLE INFO}

Article history:

Received August 26, 2021

Revised August 28, 2021

Accepted September 30, 2021

Available online December 25, 2021

Kata Kunci:

Desa Wisata, Bali Aga, Destinasi

Wisata Baru, Promosi Wisata

Keywords:

Tourism Village, Bali Aga, New Tourist Destinations, Tourism Promotion

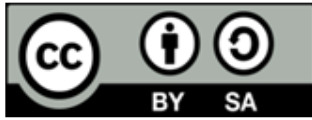

This is an open access article under the CC BY-SA license.

Copyright (c) 2021 by Author. Published by Universitas Pendidikan Ganesho.

\begin{abstract}
A B S T R A K
Kurangnya publikasi dalam bentuk manual maupun digital mengakibatkan kurangnya informasi kepada wisatawan mengenai wisata. Masyarakat atau wisatawan tidak banyak mengetahui mengenai potensi wisata yang ada di desa wisata yang terpencil. Tujuan penelitian ini adalah membantu masyarakat, khususnya di Desa Bug-Bug untuk mempromosikan objek wisata yang sedang digalakkan saat ini kepada wisatawan lokal dan mancanegara. Potensi wisata alam yang dimiliki di desa tersebut yaitu Pantai Pasir Putih dan Perkemahan Taman Harmoni Bali Bukit Asah. Jenis penelitian ini adalah deskriptif kualitatif. Beberapa metode digunakan untuk mengumpulan data dari lokasi wisata. Dilakukan sesi wawancara langsung dengan pimpinan atau tetua di desa tersebut. Setelah produk selesai akan dilakukan pengujian untuk uji ahli dan uji konten. Hasil yang diharapkan dalam riset ini adalah produk yang dihasilkan sudah dapat mewakili pemikiran dan harapan dari masyarakat untuk membantu promosi pengembangan desa wisata di desa tersebut. Melalui proses pengujian, dapat disimpulkan bahwa media yang dikembangkan layak digunakan untuk membantu promosi daerah wisata.
\end{abstract}

\begin{abstract}
A B S T RA C T
The lack of publications in manual or digital form causes a lack of information to tourists about tourism. The remote tourist village causes the public or tourists not to know much about the tourism potential. The purpose of this research is to help the community, especially in Bug-Bug Village, to promote tourism objects that are currently being promoted so that they can be promoted to local and foreign tourists. The potential for nature tourism in the village is the White Sand Beach and the Bali Harmony Park Campground, Bukit Asah. This type of research is descriptive qualitative. The method used is to collect data from tourist sites. Then conduct direct interview sessions with leaders or elders in the village. Then after the product is finished, it will be tested for expert and content tests. The expected result in this research is that the resulting product can represent the thoughts and expectations of the community to help promote the development of tourism villages in the village. Through the testing process, it can be concluded that the media developed is suitable to be used to help promote tourist areas.
\end{abstract}

\section{PENDAHULUAN}

Karangasem adalah salah satu kabupaten di Provinsi Bali bagian timur. Kabupaten Karangasem memiliki beberapa kecamatan di antaranya Kecamatan Karangasem. Kecamatan Karangasem memiliki obyek wisata alam, yaitu perbukitan, pantai, persawahan, dan air terjun. Sebagai ujung Timur Pulau Bali, Karangasem memiliki batas wilayah, yaitu utara adalah laut Jawa, selatan adalah Samudra Indonesia, barat dengan Kabupaten Klungkung, Bangli, dan Buleleng, dan batas timur adalah Selat Lombok (Jaya et al., 2019; Sucipta et al., 2019). Wilayah Kabupaten Karangasem didominasi oleh lahan kering yaitu 76.884 hektar. Berdasarkan observasi diketahui bahwa kondisi yang terjadi saat ini adalah adanya kesenjangan antara pariwisata di daerah Bali, khususnya di bagian timur. Padahal potensi yang dimiliki oleh Bali timur juga tidak kalah dengan Bali Selatan seperti pantai dengan pasir putihnya (Sumardani \& Ardika, 2016; Wisarja, 2018). Dengan akses jalan yang sudah bagus, yaitu melalui by pass Ida Bagus Mantra, Karangasem dapat ditempuh kurang lebih 2 jam dari kota Denpasar. Hal ini memudahkan wisatawan untuk berkunjung ke Kabupaten Karangasem. Kecamatan karangasem terbagi menjadi beberapa desa, yaitu salah satunya Desa 
BugBug. Desa BugBug merupakan salah satu desa yang terletak di Kecamatan Karangasem provinsi Bali. Desa BugBug merupakan desa terbesar di Karangasem yang mempunyai adat istiadat dan budaya yang diwariskan oleh nenek moyang mereka yang sampai saat ini masih dilestarikan oleh masyarakat. Secara geografis Desa Dugbug terletak di daerah pesisir pantai dan perbukitan. Bali dikenal karakteristik uniknya berupa keindahan alam yang dipadukan dengan keunikan budaya yang mengundang banyak wisatawan untuk mengunjunginya (Bekagema et al., 2016; Millenium et al., 2021). Salah satu keunikan Bali adalah keberagaman budaya yang lahir dari keberagaman masyarakatnya yang ada di desa sehingga suatu desa memiliki daya tarik yang khas dengan kehidupan sosialnya masing-masing (Aditya Dharma, 2019; Dwija Putri et al., 2017; Widiartini et al., 2019).

Karangasem memiliki Desa Baliaga yang lokasinya tidak jauh dari Desa BugBug yaitu Desa Tenganan. Kelompok masyarakat Bali terdiri dari dua kelompok besar, yaitu Bali Mula atau Bali Aga dan Bali Dataran dengan kelompok masyarakat Bali Majapahit (Darmayasa et al., 2019; Dwitiari, 2012). Dalam hal ketahanan budaya, antara desa Bali Aga ternyata ini adalah Desa Tenganan Pegringsingan memiliki ketahanan budayanya sangat tinggi (Darmawati et al., 2016; Dewi et al., 2018). Desa Penglipuran tingkat ketahanan budayanya tinggi, Desa Bayung Gede tingkat ketahanan budayanya rendah, dan yang paling rendah tingkat ketahanan budayanya adalah Desa Bugbug. Desa Tenganan yang terletak di Kecamatan Manggis, Kabupaten Karangasem, Provinsi Bali yang sering disebut desa tua yaitu Desa Tenganan. Masyarakat Desa Tenganan Pegringsingan masih tetap memegang teguh budaya dan adat-istiadat yang disebut dengan awig-awig (Respati et al., 2017; Sucitawathi et al., 2019). Desa Tenganan adalah sebuah desa tradisional di Bali yang mempertahankan aturan adat istiadat yang diwarisi oleh nenek moyang. Aturan adat tersebut meliputi letak bangunan, bentuk dan ukuran bangunan, pekarangan dan letak pura. Salah satu potensi yang ada di Desa Tenganan ini yaitu ciri khas rumah adat, kerajinan kain gringsing, anyaman bambu, ukir - ukiran, dan lukisan diatas daun lontar serta kain tenun. Tata cara kehidupan unik dan berbeda akan menjadi daya tarik wisatawan yang memberikann gambaran berharga disetiap wisatanya (Putri et al., 2012; Sucitawathi et al., 2019).

Desa Bugbug berkomitmen untuk mengembangkan desa wisata minimal untuk membantu pembangunan desa. Krama desa adat tidak perlu kena iuran ke desa adat. Desa Bugbug memiliki 12 banjar dan 7 Banjar Dinas yang memiliki upacara besar seperti Usaba Manggung, Usaba Kelod, Usaba Bukit Gundul, Usaba Gumang, Usaba Pangalapan, Usaba Pasujan, dan Usaba Kaja. Dengan status sama dengan Desa Tenganan, yaitu sebagai Desa Tua atau Desa Bali Aga, Bugbug diharapkan mampu menjadi destinasi wisata baru dengan konsep yang berbeda dari Desa Tenganan. Desa Tenganan sudah menjadi tren center pariwisata di sana, sehingga perlu dikembangkan desa wisata baru dengan melihat potensi yang ada melalui proses promosi. Promosi yang dilakukan sebelumnya adalah dengan cara membuat brosur dan menyebarkannya kepada wisatawan atau menaruh di pusat informasi. Selanjutnya, perlu dikembangkan sebuah media promosi yang dapat menjangkau lebih luas dalam waktu yang efektif, salah satunya adalah dengan menggunakan video (Kusumohendrarto \& Fitri, 2021; Yudani, 2018).

Kurangnya publikasi dalam bentuk manual maupun digital menyebabkan kurangnya informasi kepada wisatawan mengenai wisata (Fiaji et al., 2021; Indiyati et al., 2020). Karena berada di lokasi yang terpencil hal ini menyebabkan masyarakat atau wisatawan tidak banyak mengetahui mengenai potensi wisata tersebut. Diperlukan sebuah media untuk melakukan promosi, promosi sangat penting dilakukan seperti riset yang dilakukan membuat media promosi dalam bentuk video (Desmira et al., 2021; Pratiwi et al., 2017). Video yang dikembangkan adalah tentang profil untuk promosi prodi D3 Manajemen Infomatika untuk membantu prodi dalam melakukan sosialisasi untuk menjaring calon peserta didik baru dan terbukti sangat efektif untuk digunakan promosi. Temuan penelitian sebelumnya juga menyatakan bahwa video dapat menarik minat wisatawan mengunjungi tempat wisata tertentu (Prajarini \& Sayogo, 2021; Suryanto et al., 2018). Temuan penlitian sebelumnya juga menyatakan bahwa media promosi paling murah dan efektif saat ini adalah berupa video karena generasi muda sekarang lebih senang menonton dibandingkan dengan membaca (Indiyati et al., 2020; Yudani, 2018). Berdasarkan paparan di atas maka tujuan dari penelitian ini adalah mengembangkan media promosi dalam bentuk video yaitu "Video promosi potensi Desa BugBug dan Tenganan untuk meningkatkan kunjungan wisatawan ke Kabupaten Karangasem" dibuatkan video promosi. Dengan demikian, masyarakat memperoleh informasi yang luas mengenai desa wisata yang berada di Karangasem. Dengan dibuatnya video promosi desa wisata ini diharapkan agar pendapatan di Desa BugBug dan pariwisata di Karangasem bisa lebih maju dan berkembang. Video promosi potensi desa wisata Kabupaten Karangasem ini dapat bermanfaat untuk memajukan pariwisata di Kabupaten Karangasem. 


\section{METODE}

Proses penelitian yang digunakan adalah deskriptif kualitatif. Metode ini menganalisis, menggambarkan, dan meringkas berbagai kondisi, situasi dari berbagai data yang dikumpulkan berupa hasil wawacara atau pengamatan mengenai permasalahan yang diteliti yang terjadi di lapangan. Proses pertama adalah melakukan observasi dengan datang langsung ke lapangan. Kemudian pengumpulan data dilakukan dengan memakan waktu selama tiga bulan. Sumber data berasal dari wawancara langsung ke lapangan dengan metode random sampling. Data yang diperoleh adalah tentang potensi desa wisata di BugBug dan Tenganan. Data diperoleh secara langsung melalui observasi dan dokumentasi. Sumber lain dari riset ini adalah juga berasal dari internet. Data yang sudah terkumpul, kemudian disesuaikan antara data dari internet dan keadaan di lapangan, serta hasil dari wawancara sehingga dipastikan data yang ditampilkan adalah data yang sudah valid. Dalam tahap perencanaan pembuatan video promosi potensi desa ini menggunakan block diagram. Block Diagram ini menjelaskan tentang tahapan-tahapan pembuatan video promosi potensi Desa BugBug dan Tenganan dari awal hingga akhir. Tahap persiapan merupakan tahap awal dilakukan dalam pembuatan video promosi potensi desa wisata dan Desa Tenganan. Hal pertama yang dilakukan adalah menentukan lokasi tempat yang akan dijadikan sebagai video promosi. Dalam pembuatan video promosi juga membutuhkan sebuah konsep yang dijadikan sebuah video agar mencapai hasil yang maksimal. Dalam tahap ini disiapkan sebuah skenario yang jelas. Tahap perekeman dengan storyboard yang sudah dibuat dilanjutkan dengan tahap perekaman. Pengambilan gambar diambil mengikuti alur storyboard yang dimulai dari awal sampai akhir. Setelah melakukan tahap perekaman diperoleh sebuah hasil yang diproses melalui tahap pengeditan.

Tahap editing merupakan tahap pengelolaan hasil perekaman sebuah video yang diproses melalui software adobe primere. Adobe primere merupaka software untuk mengelola video. Aplikasi ini sudah sangat biasa digunakan oleh rumah produksi dan pertelevisian karena selain mudah digunakan aplikasi ini juga memiliki banyak efek. Adobe after effect merupakan aplikasi untuk mengelola video, aplikasi ini berfungsi untuk mengubah efek pada suatu video. Adobe audition CS6. Tool ini digunakan karena sudah dipercaya untuk menghasilkan video dengan kualitas bagus. Tahap uji coba ini merupakan tahapan yang akan dilakukan setelah proses pengeditan. Tahap uji coba mengontrol suatu video yang sudah diedit menjadi sebuah video dengan hasil yang maksimal. Jika belum mencapai hasi maksimal, pembuatan video kembali ke tahap awal yaitu tahap perekaman, proses editing sampai mencapai tujuan hasil yang diinginkan. Tahap publikasi ini merupakan video yang telah melalui proses perekaman, pengeditan, dan diuji coba sudah mencapai hasil yang maksimal video akan diunggah melalui media sosial, salah satunya YouTube untuk mempromosikan potensi desa wisata Desa BugBug dan Desa Tenganan. Dalam pembuatan video promosi potensi Desa Bugbug dan Desa Tenganan untuk meningkatkan kunjungan wisatawan ke Kabupaten Karangasem ini diperlukan sebuah gambaran untuk mengetahui alur cerita dari video dengaan membuat storyboard. Berikut adalah rancangan storyboard video promosi potensi Desa Bugbug dan Desa Tenganan untuk meningkatkan kunjungan wisatawan ke Kabupaten Karangasem.

\section{HASIL DAN PEMBAHASAN}

\section{Hasil}

Hasil dari media promosi ini adalah berupa video. Video promosi potensi Desa Bugbug dan Desa Tenganan sudah berhasil diimplementasikan berdasarkan Storyboard. Berikut hasil implementasi dan keterangan terkait dengan video yang sudah dihasilkan untuk melakukan promosi sesuai dengan alur atau narasi yang sudah disusun sebelumnya dalam bentuk Storyboard seperti pada Tabel 1.

Tabel 1. Storyboard rancangan video

\begin{tabular}{|c|c|c|}
\hline No & Deskripsi / Gambar & Durasi \\
\hline 1 & Opening & 20 Detik \\
\hline 2 & $\begin{array}{l}\text { Menampilkan Judul "Natural Tourism and Cultural Tourism in the Karangasem } \\
\text { District and Manggis District" }\end{array}$ & 5 detik \\
\hline 3 & $\begin{array}{l}\text { Menampilkan peta di Provinsi Bali, Fokus peta di Bali Timur di Kecamatan } \\
\text { Karangasem dan Manggis }\end{array}$ & 30 detik \\
\hline 4 & Menampilkan cuplikan video Kabupaten karangasem & 20 detik \\
\hline 5 & Menampilkan Judul “Desa Tenganan” & 2 detik \\
\hline 6 & $\begin{array}{l}\text { Menampilkan candi masuk desa tenganan dan Menampilkan situasi di Desa } \\
\text { Tenganan dan karya seni }\end{array}$ & 30 detik \\
\hline 7 & $\begin{array}{l}\text { Menampilkan hasil wawancara di Desa Tenganan, Menampilkan objek wisata desa } \\
\text { tenganan, dan produksi kain gringsing. }\end{array}$ & 2 menit \\
\hline
\end{tabular}




\begin{tabular}{lll}
\hline No & \multicolumn{1}{c}{ Deskripsi / Gambar } & Durasi \\
\hline 8 & Menampilkan orang membuat ate & 30 detik \\
9 & Masyarakat di desa tenganan membuat tulisan di daun lontar. & 30 detik \\
10 & Menampilkan wisata candidasa & 30 detik \\
11 & Menampilkan Judul “Desa Bugbug” & 2 detik \\
12 & Menampilkan candi Desa Bugbug dan potensi wisata di Desa Bugbug & 20 detik \\
13 & Menampilkan wawancara di Desa Bugbug dan menampilkan objek wisata white & 1 menit \\
& sand beach serta potensi Bukit asah & \\
14 & Meanmpilkan rumah tua pondok sayap & 20 detik \\
15 & Menampilkan wisata pasih kelod & 20 detik \\
16 & Menampilkan pemandian pengalapan & 25 detik \\
17 & Menampilkan ladang pertanian di Desa Bugbug & 20 detik \\
18 & Menampilkan aktifitas masyarakat didesa bugbug. & 15 detik \\
19 & Menampilkan Logo Undiksha & 10 detik \\
20 & Menampilkan credit & 20 detik \\
\hline
\end{tabular}

Pada tahap ini selanjutnya dilakukan pengujian lagi terkait dengan uji materi/konten dengan uji media. Pakar uji konten dilakukan dengan menyebarkan kuesioner dan melakukan demo video langsung kepada prajuru desa dan masyarakat. Kemudian pengujian media dilakukan terhadap orang yang memang memiliki keahlian pada bidang video. Berdarkan hasil pengujian, apabila ada revisi terkait dengan produk maka akan dilakukan revisi sesuai dengan masukan penguji sampai hasil dari pengujian ini adalah layak. Pengujian Ahli Materi/Konten video melibatkan 2 pakar dengan rentangan nilai $90 \%$ dikategorikan sangat baik (SB). Uji Ahli Media dengan 2 orang pakar diperoleh nilai 74\% yang dikategorikan baik (B). Artinya, dengan skor $90 \%$ dan 74\% video sudah layak digunakan untuk mempromosikan potensi Desa Bugbug dan Desa Tenganan. Adapun hasil video yang dikembangkan disajikan pada gambar 1.
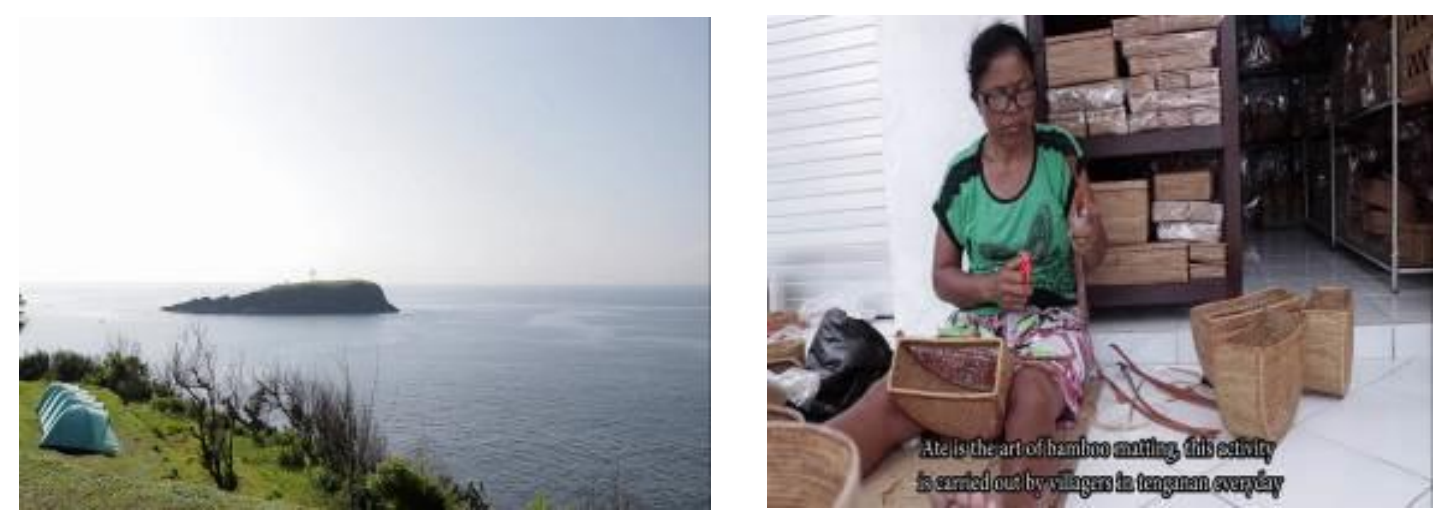

Gambar 1. Hasil Media Promosi untuk Membantu Promosi Desa Wisata

\section{Pembahasan}

Pariwisata merupakan komoditas ekonomi baru yang memiliki upaya untuk memperkenalkan wisata lokal (Andrinata et al., 2016; Paramita \& Putra, 2020). Salah satu cara untuk mewujudkan pariwisata yang unggul yaitu dengan mengembangkan sebuah desa wisata. Desa wisata adalah salah satu bentuk industri yang mendorong wisatawan sebagai konsumen untuk melanjutkan perjalanan wisata ke desa wisata (Ariawan et al., 2021; Citra \& Sarmita, 2019). Desa dapat dikatakan desa wisata karena memiliki potensi wisata yang dapat dikembangkan, memiliki tradisi dan kebudayaan yang menarik perhatian. Desa Tenganan adalah sebuah desa tradisional di Bali yang mempertahankan aturan adat istiadat yang diwarisi oleh nenek moyangnya yang meliputi letak bangunan, bentuk dan ukuran bangunan, pekarangan dan letak pura. Salah satu potensi yang ada di Desa Tenganan ini yaitu ciri khas rumah adat, kerajinan kain gringsing, anyaman bambu, ukir - ukiran, dan lukisan diatas daun lontar serta kain tenun. Tata cara kehidupan unik dan berbeda akan menjadi daya tarik wisatawan yang memberikann gambaran berharga di setiap wisatanya. Hal tersebut yang membuat desa ini cocok untuk dipromosikan. Tujuan pengembangan industri pariwisata yaitu meningkatkan pendapatan desa ataupun pendapatan devisa negara. Selain itu, melalui industri pariwisata ini diharapkan sebagai memicu dalam pembangunan ekonmi di berbagai sektor (Andrinata et al., 2016; Ariawan et al., 2021; Rhosyida \& Jailani, 2014). Salah satu cara untuk mempromosikan desa wisata yaitu melalui video promosi. Perkembangan teknologi yang begitu cepat membuat video sangat diminati oleh kalangan masyarakat (Amin \& Sundari, 2020; Nurrohmah et al., 2018; 
Pramana et al., 2016). Video promosi dapat menyajikan identitas desa wisata sehingga layak untuk digunakan sebagai media promosi. Selain itu video promosi menjadi media promosi yang efektif dan terjangkau.

Video dapat digunakan sebagai media promosi agar produk yang dipromosikan dikenal lebih luas dan dapat menarik minat pengunjung. Video promosi berfungsi untuk mempromosikan produk yang berisikan keunggulan lable atau merk produk tersebut. Temuan penelitian sebelumnya juga menyatakan bahwa video promosi sangat digemari oleh masyarakat, sehingga efektif untuk digunakan (Desmira et al., 2021; Indiyati et al., 2020). Temuan penelitian lainnya juga menyatakan bahwa video promosi sangat menarik sehingga efektif digunakan (Indiyati et al., 2020). Video promosi yang dikembangkan membuat masyarakat dapat memperoleh informasi yang luas mengenai desa wisata yang berada di Karangasem. Dengan dibuatnya video promosi desa wisata ini diharapkan pariwisata di Karangasem maju dan berkembang. Video promosi potensi desa wisata Kabupaten Karangasem ini dapat bermanfaat untuk memajukan pariwisata di Kabupaten Karangasem

\section{SIMPULAN}

Media promosi yang digunakan untuk mempromosikan Desa Bugbug dan Desa Tenganan adalah dalam bentuk video. Adapun hasil uji media menghasilkan nilai sangat baik dan uji konten memperoleh nilai baik. Media yang dikembangkan layak digunakan untuk membantu promosi daerah wisata di Desa BugBug dan Tengangan sebagai destinasi desa wisata. Media yang dikembangkan sangat efektif karena dapat dengan mudah disebarkan melalui media sosial seperti youtube dan lebih mudah untuk dibagikan melalui akun facebook dan instagram untuk mempromosikan desa wisata di kawasan Bali Timur.

\section{DAFTAR RUJUKAN}

Aditya Dharma, I. M. (2019). Pengembangan Buku Cerita Anak Bergambar dengan Insersi Budaya Lokal Bali terhadap Minat Baca dan Sikap Siswa Kelas V SD Kurikulum 2013. Journal for Lesson and Learning Studies, 2(1), 53-63. https://doi.org/10.23887/jlls.v2i1.17321.

Amin, F., \& Sundari, H. (2020). EFL Students ' Preferences on Digital Platforms during Emergency Remote Teaching : Video Conference, LMS , or Messenger Application? Studies in English Language and Education, 7(2), 362-378. https://doi.org/10.24815/siele.v7i2.16929.

Andrinata, Sumarmi, \& I Komang Astina. (2016). Pengembangan Modul Geografi Pariwisata Berbasis Paket Wisata Pulau Lombok sebagai Upaya Memupuk Rasa Cinta Tanah Air pada Mahasiswa. Jurnal Pendidikan: Teori, Penelitian, Dan Pengembangan, 1(10), 1999-2003. https://doi.org/10.17977/jp.v1i10.7339.

Ariawan, I. W. A. P., Antara, M., Udayana, \& Arida, I. N. S. (2021). Pengembangan Desa Muntigunung sebagai Desa Wisata Baru di Kecamatan Kubu Kabupaten Karangasem. Jurnal Master Pariwisata, 7(2).

Bekagema, M. D., Mahadewi, L. P. P., \& Tastra, I. D. K. (2016). Pengembangan Video Pembelajaran Budaya Masyarakat Hindu Bali Kelas IV SDN 3 Banjar Tegal. Jurnal Edutech Undiksha, 4(3). https://doi.org/10.23887/jeu.v4i3.8561.

Citra, I. P. A., \& Sarmita, I. M. (2019). Pemetaan Potensi Wisata untuk Pengembangan Desa Wisata Muntigunung di Desa Tianyar Barat. Jurnal Widya Laksana, 8(1). https://doi.org/10.23887/jwl.v8i1.16606.

Darmawati, Wijana, Astiningsih, \& Mayun. (2016). Identifikasi dan Karakterisasi Tanaman Pewarna Alam Tenun Pegringsingan Desa Tenganan. MUDRA: Jurnal Seni Budaya, 6(1).

Darmayasa, J. B., Wahyudin, \& Mulyana, T. (2019). Ethnomathematics: Predicting the Average Height of the Bali Mula Ancestors using Linear Regression. Jurnal Ilmiah Matematika, 8(1). https://doi.org/10.25273/jipm.v8i1.3863.

Desmira, D., Aribowo, D., Ekawati, R., \& Wahyuni, A. P. (2021). Video Promosi Wisata "Cikal Adventure” Di Kecamatan Padarincang. Kaibon Abhiyana, 3(2). https://doi.org/10.30656/ka.v3i2.2940.

Dewi, P. E. R., Suwindia, I. G., \& Sudarsana, I. K. (2018). Ethic Educations Of Leadership in Tenganan Pegringsingan Traditional Village. Vidyottama Sanatana, 2(2). https://doi.org/10.25078/ijhsrs.v2i2.628.

Dwija Putri, I. G. A. M. A., Ulupui, I. G. K. ., \& Wirawati, N. G. P. (2017). Pengaruh Good Corporate Governance dan Budaya Tri Hita Karana pada Kinerja Bank Perkreditan Rakyat. Jurnal Ilmiah Akuntansi Dan Bisnis, 17. https://doi.org/10.24843/jiab.2017.v12.i01.p03.

Dwitiari, M. C.. (2012). The Genetic Variations of Indigenous Balinese (Bali Mula) Community At Sembiran Village Using Microsatelite Dna Markers. Jurnal Biologi Udaya, 16(1).

Fiaji, N. A., Brata, K. C., \& Zulvarina, P. (2021). Aplikasi AR-CA (Augmented Reality Relief Candi Jago) sebagai 
Upaya Pendokumentasian Digital Relief Candi Jago dan Pengenalan Wisata Sejarah di Malang. Jurnal Teknologi Informasi Dan Komunikasi, 8(4). https://doi.org/10.25126/jtiik.2021844447.

Indiyati, D., Khusnia, H. N., \& Chotijah, S. (2020). Optimalisasi Gerakan Sadar Wisata melalui Produksi Video Promosi Desa Wisata. Jurnal Pengabdian Kepada Masyarakat, 5(2). https: //doi.org/10.30653/002.202052.510.

Jaya, Ngakan, A. W., M., D. K. S., \& Putu, S. (2019). Mapping the Potential for Tourism Strategic Areas to Improve the Equality of Development in Bali. Matec Web of Conferences, 276. https://doi.org/10.1051/matecconf/201927602008.

Kusumohendrarto, raden hadapiningrani, \& Fitri, N. D. (2021). Perancangan Video Destinasi Wisata Kulon Progo sebagai Pembentuk City Branding Daerah. Jurnal Desain Komunikasi Visual Dan Multimedia, 7(1). https://doi.org/10.33633/andharupa.v7i01.4140.

Millenium, A. S., Suardana, I. W., \& Negara, I. M. K. (2021). Pengaruh Digital Marketing dan Brand Awareness terhadap Keputusan Pembelian pada Startup Bike Rental Bananaz Bali. Jurnal IPTA, 9(1). https://doi.org/10.24843/IPTA.2021.v09.i01.p17.

Nurrohmah, F., Putra, F. G., \& Farida, F. (2018). Development of Sparkol Video Scribe Assisted Learning Media. Formatif: Jurnal Ilmiah Pendidikan MIPA, 8(3), 233-250. https://doi.org/10.30998/formatif.v8i3.2613.

Paramita, I. B. G., \& Putra, I. G. G. P. A. (2020). New Normal Bagi Pariwisata Bali di Masa Pandemi Covid 19. Jurnal Ilmiah Pariwisata Agama Dan Budaya, 5(2). https://doi.org/10.25078/pba.v5i2.1723.

Prajarini, D., \& Sayogo, D. (2021). Pengaruh Desain Post Instagram terhadap Minat Pembelian Produk UMKM Kedai Kopi di Kabupaten Sleman. Andharupa: Jurnal Desain Komunikasi Visual \& Multimedia, 7(1). https://doi.org/10.33633/andharupa.v7i01.4139.

Pramana, I. P. A., Tegeh, I. M., \& Agung, A. A. G. (2016). Pengembangan Video Pembelajaran IPA Kelas VI di SD N 2 Banjar Bali Tahun 2015/2016. E-Journal Edutech Universitas Pendidikan Ganesha Jurusan Teknologi Pendidikan, 5(2). https://doi.org/10.23887/jeu.v4i2.7631.

Pratiwi, D. P. E., Ayomi, P. N., \& Candra, K. D. P. (2017). Balinese Arts and Cultur as Tourism Commodity In Bali Tourism Promotion Videos. Mudra: Jurnal Seni Budaya, 32(3). https://doi.org/10.31091/mudra.v32i3.178.

Putri, K. M., Hardoyo, S. R., \& Santosa, L. W. (2012). Desa Adat Tenganan Pegringsingan dalam Pengelolaan Hutan di Desa Tenganan, Kecamatan Manggis, Karangasem, Bali. Majalah Geografi Indonesia, 26(1). https://doi.org/10.22146/mgi.13402.

Respati, D., Sumunar, S., Suparmini, S., \& Setyawati, S. (2017). Masyarakat Desa Adat Tenganan Pegringsingan. Jurnal Penelitian Humaniora, 22(2). https://doi.org/10.21831/hum.v22i2.19929.

Rhosyida, N., \& Jailani, J. (2014). Pengembangan Modul Matematika SMK Bidang Seni, Kerajinan, dan Pariwisata Berbasis Open-Ended Problem sebagai Implementasi KTSP. Jurnal Riset Pendidikan Matematika, 1(1), 35. https://doi.org/10.21831/jrpm.v1i1.2662.

Sucipta, Utama, Dewi, \& Yuliarmi. (2019). Smart Tourism Destination Management in Karangasem Regency of Indonesia. Russian Journal of Agricultural and Socio-Economic Science, 93(9). https: //doi.org/10.18551/rjoas.2019-09.28.

Sucitawathi, D., Dewi, N. L. Y., \& Joniarta, I. W. (2019). Responsivitas Kebijakan Lokal dalam Menghadapi Dinamika Sosial di Desa Tradisional Bali Aga: Kasus Desa Tenganan Pegringsingan, Karangasem Bali. Jurnal Administrasi Negara, 9(2). https://doi.org/10.33005/jdg.v9i2.1632.

Sumardani, N. L. G., \& Ardika, I. N. (2016). Populasi dan Performa Reproduksi Babi Bali Betina Di Kabupaten Karangasem sebagai Plasma Nutfah Asli Bali. Majalah Ilmiah Peternakan, 19(3). https://doi.org/10.24843/MIP.2016.v19.i03.p04.

Suryanto, A., Sukamta, S., Kusuma, D. A., \& Wardhani. (2018). Pelatihan Pembuatan Profil Desa Dengan Memakai Window Movie Marker Bagi Perangkat Desa Jangli Krajan Kecamatan Candisari Semarang. Rekayasa, 16(1). https://doi.org/10.15294/rekayasa.v16i1.15083.

Widiartini, P. D. O., Made Putra, M. P., \& Manuaba, I. B. S. (2019). Pengaruh Model Pembelajaran Group Investigation Berbasis Tri Hita Karana terhadap Kompetensi Pengetahuan IPA. Jurnal Ilmiah Sekolah Dasar. https://doi.org/10.23887/jisd.v3i3.19476.

Wisarja. (2018). Hinduism Humanity at Ratu Bagus Ashram in The Muncan Village, Selat District, Karangasem Regency. Vidyottama Sanatana, 2(1). https://doi.org/10.25078/ijhsrs.v2i1.521.

Yudani, H. D. (2018). Perancangan Video Iklan Destination Branding Kabupaten Kediri. Nirmana, 17(1). https://doi.org/10.9744/nirmana.17.1.22-29. 